\title{
Prevalence and molecular characterization of infectious bronchitis virus isolated from chicken in Bangladesh
}

\author{
Zafar Ahmed Bhuiyan ${ }^{1 *}$, Md. Zulfekar Ali²*, Mohammad Moktader Moula ${ }^{3}$, Md. Giasuddin² and \\ Zahed Uddin Mahmood Khan ${ }^{1}$
}

1. Department of Botany, Jahangirnagar University, Savar, Dhaka 1341, Bangladesh; 2. Animal Health Research Division, Bangladesh Livestock Research Institute, Savar, Dhaka 1341, Bangladesh; 3. Central Poultry Laboratory, Nourish Poultry and Hatchery Ltd., Dhaka, Bangladesh.

*These authors contributed equally to this work.

Corresponding author: Md. Giasuddin, e-mail: mgias04@blri.gov.bd

Co-authors: ZAB: rubel@nourish-poultry.com, MZA: zulfekarvet@gmail.com, MMM: moula.moktader@gmail.com,ZUMK: zahed@juniv.edu

Received: 10-01-2019, Accepted: 13-05-2019, Published online: 28-06-2019

doi: 10.14202/vetworld.2019.909-915 How to cite this article: Bhuiyan ZA, Ali MZ, Moula MM, Giasuddin M, Khan ZUM (2019) Prevalence and molecular characterization of infectious bronchitis virus isolated from chicken in Bangladesh, Veterinary World, 12(6): 909-915.

\begin{abstract}
Aim: The present study was aimed to determine the prevalence of infectious bronchitis virus (IBV) as well as virus isolation, identification, and molecular characterization of various strains circulating in Bangladesh.

Materials and Methods: A total of 371 swabs and organ samples were collected from four types of chicken including layer, Sonali (local), broiler, and broiler breeder under eight districts (Rangpur, Bogura, Tangail, Dhaka, Gazipur, Mymensingh, Jamalpur, and Cumilla) during 2014-2016 in Bangladesh.

Results: Out of 371 samples, 65 samples were positive in reverse transcriptase polymerase chain reaction (RT-PCR) for molecular identification of IBV. The overall prevalence was $17.52 \%$ recorded and among the selected types of chicken, the highest prevalence of IBV was found in layer that was $42.22 \%$ followed by $17.24 \%$ in Sonali, $14.93 \%$ in broiler breeder, and lowest prevalence was $11.94 \%$ in broiler chicken, respectively. Moreover, the prevalence of IBV was recorded highest in aged chicken at 41-60 weeks, which was $54.55 \%$ in layer, $27.27 \%$ in Sonali, and, afterward, $14.68 \%$ was found in broiler breeder, respectively. Frequency of IBV more frequently in winter (22.67\%) followed by rainy (15.87\%) and summer season (11.58\%). The highest prevalence of IBV was found Tangail district (41.67\%) followed by Mymensingh (24.42\%), Gazipur (19.32\%), Dhaka (15.38\%), Jamalpur (16.67\%), Bogura (13.68\%), Cumilla (5.88\%), and Rangpur (9.26\%), respectively. Samples that were found high positive in IBV RT-PCR (Ct value below 30) were subjected to inoculation into chicken egg embryo to observe characteristic changes in chicken embryo. Swabs and organ samples were processed and passaged in 9-day-old embryonated chicken eggs through allantoic cavity route. IBV virus suspected samples inoculated into chicken egg embryos after 3-5 passages showed dwarfing and curling of the embryos which are characteristic lesions of IBV. Allantoic fluid was collected from all inoculated eggs and performed partial sequencing of S1 gene for three isolates. After sequencing, the phylogenetic tree was constructed from the nucleotide sequences of IBV isolates. Two of the isolates are 4/91 IBV and another one matched with QX-like IBV.
\end{abstract}

Conclusion: The results revealed that the three isolates from different places in Bangladesh were identified for the $1^{\text {st }}$ time as which will help for IBV control strategy.

Keywords: chicken, infectious bronchitis virus, isolation, molecular, prevalence.

\section{Introduction}

The poultry industry in Bangladesh has grown leaps and bound since the past two decades. Poultry farming not only assists in upgrading the financial condition but also makes a substantial contribution to human nutrition [1]. The total contribution of livestock subsectors to gross domestic products in Bangladesh is approximately $1.54 \%$ and in agricultural products $13.62 \%$ [2]. It also generates $13 \%$ of foreign

Copyright: Bhuiyan, et al. Open Access. This article is distributed under the terms of the Creative Commons Attribution 4.0 International License (http://creativecommons.org/licenses/ by/4.0/), which permits unrestricted use, distribution, and reproduction in any medium, provided you give appropriate credit to the original author(s) and the source, provide a link to the Creative Commons license, and indicate if changes were made. The Creative Commons Public Domain Dedication waiver (http:// creativecommons.org/publicdomain/zero/1.0/) applies to the data made available in this article, unless otherwise stated. currency and provides $20 \%$ fulltime employment and $45 \%$ partial employment of rural population [2]. However, it is the matter of regret that poultry industry in Bangladesh continuously facing challenges in several ways. Increased prevalence of disease outbreaks which reemergence of various pathogens with higher virulence due to constant natural evolution of variant strains as a result of recombination of virus and frequent use of live vaccine are the main reasons for such challenges $[3,4]$.

One of the most economical important diseases of poultry is infectious bronchitis virus (IBV) [5]. It is highly contagious and causing devastating economic losses to chickens [6,7]. The virus causes respiratory disease characterized by tracheal rales, coughing, and sneezing along with excess accumulation of mucus in bronchi and reduced growth rate in broilers, nephritis, 
urolithiasis, and irreparable damage to oviduct, leading to abnormal eggs production with high mortality rates in affected poultry flocks $[8,9]$. IBV is an enveloped, positive-sense, single-stranded RNA virus, belonging to the genus Gamma coronavirus [10]. The spike (S) glycoprotein is cleaved into two smaller proteins, namely S1 (amino-terminal component) and S2 (carboxy-terminal component). The S1 portion has two hypervariable regions which cause virus neutralization and serotype-specific antigenic determinants that are responsible for binding to the host cell, neutralization, and immune response [11] and also important for involving pathogenicity of the virus to the host [12].

IBV can affect chicken of all ages [13]. However, chicks of 2 to 3 weeks of age are extremely susceptible. Mortality rates as high as $40 \%-90 \%$ were observed in affected chicks $[14,15]$. The disease is transmitted through the air-borne, mechanical transmission between birds, houses, and farms. Air-borne transmission mainly occurs through aerosol and mechanical transmission occurs by personal contact, material, and equipment sharing in between farm and flock. Confirmatory diagnosis of IB can be achieved by a number of tests including agar gel precipitation test, hemagglutination inhibition, and enzyme-linked immune sorbent assay. The more traditional methods used to determine the serotype of the virus include virus isolation and neutralization tests which are being fast replaced with rapid, specific, and confirmatory tests such as reverse transcriptase polymerase chain reaction (RT-PCR) and restriction fragment length polymorphism [16]. The virus isolation is usually performed in specific pathogen free (SPF) 9-11-day-old embryonated chicken eggs (ECE) [17]. RT-PCR has been used mostly for determining field strain of IBV. The antigenic variation of spike protein, especially S1 subunit protein, is determined by nucleotide sequencing method [7].

The present study was aimed to determine the prevalence of IBV as well as virus isolation, identification, and molecular characterization of various strains circulating in Bangladesh.

\section{Materials and Methods}

\section{Ethical approval}

The Animal Ethics Committee of Bangladesh Livestock Research Institute approved the study.

\section{Sample collection and preparation}

Oropharyngeal, tracheal, and cloacal swab samples were collected in virus transport media containing falcon tube and organ samples (trachea, lungs, and kidney) which were collected in sterilized zipper-lock bag from the breeder, broiler, layer, and Sonali (local) chicken that was showing clinical respiratory sign from each sampling area. The chickens were vaccinated with IBV vaccine against MA5, H120, and IB 4/91 strain according to standard vaccine schedule from a commercial source. A total number of $371 \mathrm{swab}$ and organ samples were collected from the respective farm. Among them, broiler breeder $(\mathrm{n}=134)$, layer $(n=45)$, Sonali $(n=58)$, and broiler $(n=134)$ were considered for sampling. After collection, the sample transported in ice box and stored at $-20^{\circ} \mathrm{C}$ refrigerator in the laboratory. The organ samples were taken into sterile pestle and homogenized with the help of sterile scissors and mortar and added 20\% phosphate-buffered saline to make a suspension and then centrifuged at $1000 \mathrm{rpm}$ for $10 \mathrm{~min}$. Supernatant fluid was taken by syringe for RNA extraction. Swab samples were homogenized by vortexing at 2-3 s and selected for RNA extraction.

\section{RNA extraction for RT-PCR}

RNA extraction was done with Purelink RNA Mini Kit, P/N: 12183018A by Invitrogen, USA, as per manufacturer's instructions.

\section{Real-time RT-PCR for IBV detection}

The one-step RT-PCR was performed using S1 gene-specific primer and probe with thermal condition described by Callison et al. [18] (Tables-1 and 2). RT-PCR of the extracted RNA was conducted using the commercially available AgPath-ID One-Step RT-PCR kit (Invitrogen, USA). Thermocycler used for PCR was Applied Biosystem 7500 by Life Technologies.

\section{Propagation and isolation of virus}

Samples that were found high positive in IBV RT-PCR $(\mathrm{Ct} \leq 30)$ were subjected to inoculate at the $9^{\text {th }}$ day SPF chicken egg embryo through allantoic cavity route and observe curling and dwarfing [7] in chicken embryo according to the OIE guideline [15]. After $48 \mathrm{~h}$ of inoculation, eggs were chilled at $4^{\circ} \mathrm{C}$ for at least $6 \mathrm{~h}$ and allantoic fluid was harvested.

\section{Sequences and phylogenetic analysis}

Allantoic fluid in FTA card was sent to the CEVA Phylexia Laboratory, Hungary, for Sanger sequencing of IBV. Sequences of the S1 gene of the Bangladeshi IBV isolates were compared with published IBV sequences deposited in the GenBank database using a BLAST. Sequence identities by BLAST analysis were included in alignment and phylogenetic construction. A phylogenetic tree of the nucleotide sequences was constructed using $\mathrm{R}$ version 3.4.0 and under package phangorn version 2.4.0, and package ape version 5.1 (R Core Team, USA) [19] (Figure-1).

\section{Results}

A total of 371 samples were collected and tested for IBV by the real-time RT-PCR test. The overall prevalence of IBV was found to be $17.52 \%(65 / 371)$. Among the selected types of chicken, the highest prevalence of IBV was found in commercial layer chicken that was $42.22 \%(19 / 45)$ and the lowest prevalence was showed broiler chicken as $11.94 \%(16 / 134)$. The prevalence of $17.24 \%(10 / 58)$ and $14.93 \%(20 / 134)$ was showed in Sonali and broiler breeder chicken, respectively (Table-3).

According to the age of the chicken in both commercial layer and Sonali chicken, the highest 
Table-1: IBV primer and probe details.

\begin{tabular}{llcc}
\hline Name & Sequence (5' to $\mathbf{3}^{\prime}$ ) & Nucleotide positions & Reference \\
\hline IBV5 GU391 & 5'-GCT TIT GAG CCT AGC GTT-3' $^{\prime}$ & $391-408$ \\
IBV5 GL533 & 5'-GCC ATG TTG TCA CTG TCT ATT G-3' & $533-512$ \\
IBV5 G probe & 5'-FAMCAC CAC CAG AAC CTG TCA CCT C-BHQ1-3' & $494-473$ \\
\hline
\end{tabular}

IBV $=$ Infectious bronchitis virus

Table-2: Master mix composition and RT-PCR condition.

\begin{tabular}{llcc}
\hline S. No. & Reagent & Volume $(\boldsymbol{\mu l})$ & Thermal profile \\
\hline 1 & $2 \times-R T-P C R$ buffer & 12.5 & $50^{\circ} \mathrm{C}$ for $30 \mathrm{~min} ; 94^{\circ} \mathrm{C}$ for $15 \mathrm{~min} ; 40 \mathrm{cycles}$ of \\
2 & $25 \times$ RT-enzyme & 1.0 & $94^{\circ} \mathrm{C}$ for $15 \mathrm{~s}$ followed by $60^{\circ} \mathrm{C}$ for $60 \mathrm{~s}$ \\
3 & Forward primer & 1.25 & \\
4 & Reverse primer & 1.25 & \\
5 & Probe & 0.25 & \\
6 & Nuclease-free water & 3.75 & \\
7 & Template RNA & 5.0 & \\
& Total & 25.0 & \\
\hline
\end{tabular}

RT-PCR $=$ Reverse transcriptase polymerase chain reaction

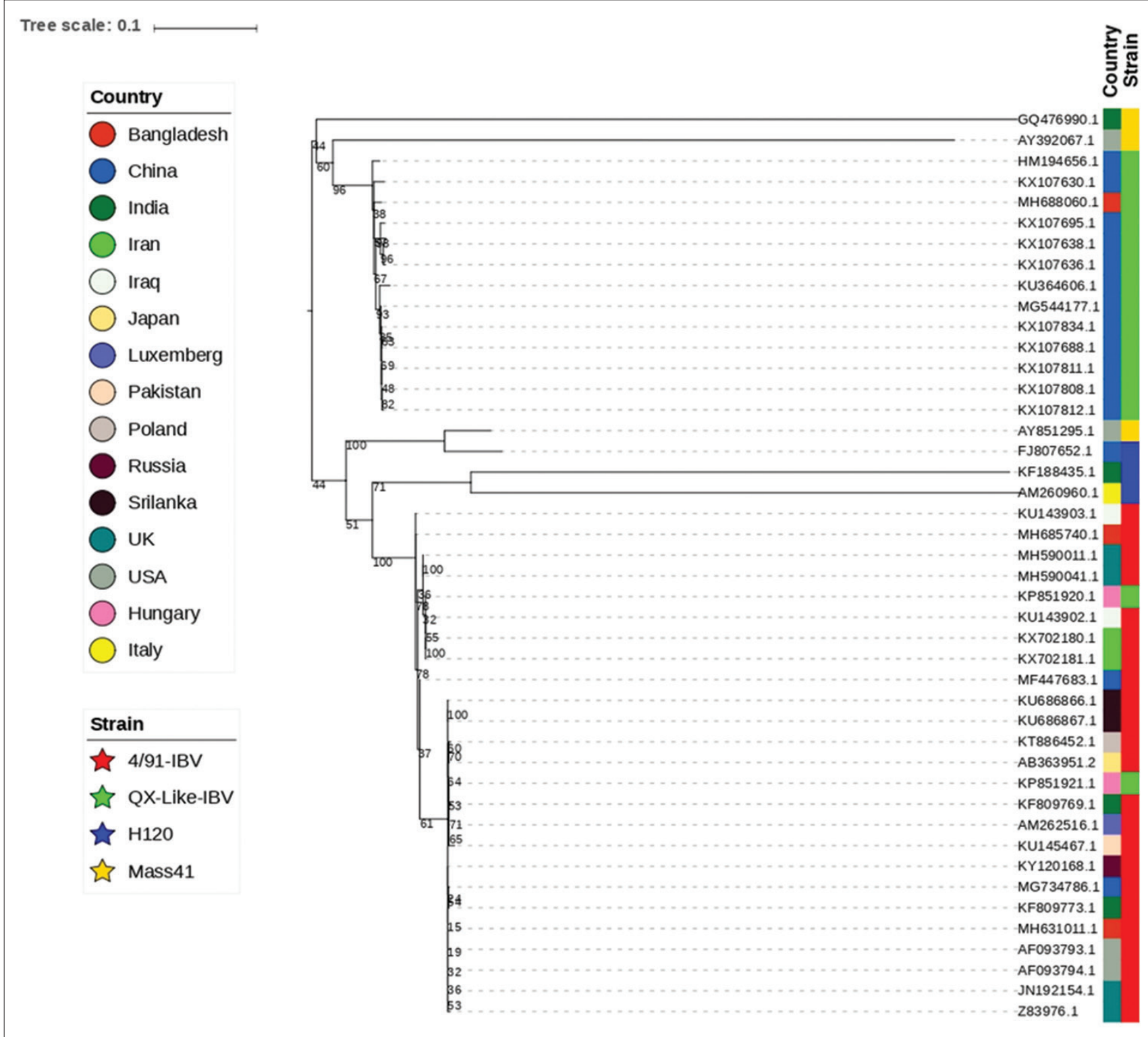

Figure-1: Phylogenetic tree of amino acid sequences of S1 genes of isolated infectious bronchitis virus. The isolates used in this study indicated by red color. 
prevalence was found in age between 41 and 60 weeks, which was $54.55 \%(6 / 11)$ and $27.27 \%(3 / 11)$, respectively. However, in case of broiler breeder chicken, it was highest at 21-40 weeks of age than 41-60 weeks of age, which was $16 \%(4 / 25)$ and $14.68 \%$ (16/109), respectively. On the other hand, in broiler chicken, age divided into two groups due to short life cycle and found prevalence $12.5 \%(1 / 8)$ at $0-16$ days of age and prevalence $11.9 \%(15 / 126)$ at $17-32$ days of age (Table-4).

Three years (2014-2016) were observed during the study period, among three seasons, highest $22.67(34 / 150)$ and lowest $11.58 \%$ (11/95) prevalence was found in winter and summer season correspondingly. In rainy season, $15.87 \%(20 / 126)$ prevalence was found (Table-5).

Table- 6 shows the prevalence of IBV in eight different districts over Bangladesh, where 371 samples were tested and found the highest prevalence in Tangail district. It was $41.67 \%$ (5/12) chickens ware affected. The lowest prevalence was found in Cumilla district as $5.88 \%(1 / 17)$. The prevalence of another six districts was $9.26 \%(5 / 54), 13.68 \%$ (13/95), $15.38 \%(2 / 13), 19.32 \%$ (17/88), $24.42 \%$ (21/86), and $16.67 \%(1 / 6)$ of Rangpur, Bogura, Dhaka, Gazipur, Mymensingh, and Jamalpur, respectively.

The identified IBV samples were inoculated into 9-day-old SPF ECE through chorioallantoic membrane route. The chicken embryos were shown characteristic lesions of growth such as curled and dwarfed embryos with covered by a thickened amnion after the third passage propagation. Then, IBV was isolated and reconfirmed by RT-PCR.

The partial nucleotide sequence analysis of S1 glycoprotein gene was performed in the isolate $\mathrm{CK} /$ $\mathrm{BD} / \mathrm{IBV} / \mathrm{NPHL} 1, \mathrm{CK} / \mathrm{BD} / \mathrm{IBV} / \mathrm{NPHL} 2$, and $\mathrm{CK} /$ $\mathrm{BD} / \mathrm{IBV} / \mathrm{NPHL} 3$ and found further defined genetic relationship with two IBV subtypes; one isolate was QX-like IBV and another two isolates were 4/91 IBV circulating in the selected regions, shown in phylogenetic tree (Figure-1). The sequenced nucleotides were submitted into GenBank under accession number MH631011.1 (isolate: $\mathrm{CK} / \mathrm{BD} / \mathrm{IBV} / \mathrm{NPHL} 1$ ), MH688060.1 (isolate: CK/BD/IBV/NPHL2), and MH685740.1 (isolate: CK/BD/IBV/NPHL3).

The phylogenetic analysis demonstrated that the isolates of QX-like IBV are 99\% related with isolated of China (accession no. KX107695.1) and two isolates of IBV 4/91 were related with Indian isolates (KF809773.1) and Poland isolates (KT886452.1). The results indicate that both QX-like IBV and 4/91 strains are circulating in chickens in Bangladesh.

\section{Discussion}

In this study, the prevalence and characterization of IBV in between 2014 and 2016 were identified. The prevalence of IBV was widespread in the selected areas of Bangladesh and overall $17.52 \%$ prevalence was found by identification of S1 gene in quantitative PCR (qPCR). Overall, 58\% seroprevalence of IBV were

Table-3: Prevalence of infectious bronchitis virus according to the type of poultry.

\begin{tabular}{|c|c|c|c|c|c|}
\hline \multirow[t]{2}{*}{ S. No. } & \multirow[t]{2}{*}{ Type } & \multirow[t]{2}{*}{ Total sample tested } & \multicolumn{3}{|c|}{ Results } \\
\hline & & & Positive & Negative & Prevalence (\%) \\
\hline 1 & Commercial layer & 45 & 19 & 26 & 42.22 \\
\hline 2 & Sonali & 58 & 10 & 48 & 17.24 \\
\hline 3 & Broiler & 134 & 16 & 118 & 11.94 \\
\hline 4 & Broiler breeder & 134 & 20 & 114 & 14.93 \\
\hline Total & & 371 & 65 & 306 & 17.52 \\
\hline
\end{tabular}

Table-4: Prevalence of infectious bronchitis virus according to the age of poultry.

\begin{tabular}{lcccc}
\hline Type & Age & Total sample tested & \multicolumn{2}{c}{ Results } \\
\cline { 4 - 5 } & & & Positive sample & Prevalence (\%) \\
\hline Commercial layer & $0-20$ weeks & 9 & 2 & 22.22 \\
& $21-40$ weeks & 12 & 4 & 33.33 \\
& $41-60$ weeks & 11 & 6 & 54.55 \\
& $61-80$ weeks & 13 & 7 & 53.85 \\
Sonali & & 45 & 19 & 42.22 \\
& $0-20$ weeks & 6 & 1 & 16.67 \\
& $21-40$ weeks & 31 & 5 & 16.13 \\
Broiler & $41-60$ weeks & 11 & 3 & 27.27 \\
& $61-80$ weeks & 10 & 1 & 10.00 \\
Broiler breeder & & 58 & 1 & 17.24 \\
& $0-16$ days & 8 & 15 & 12.50 \\
Total & $17-32$ days & 126 & 16 & 11.90 \\
& & 134 & 4 & 11.94 \\
& $21-40$ weeks & 25 & 16 & 16.00 \\
\end{tabular}


Table-5: Prevalence of infectious bronchitis virus according to the season of poultry.

\begin{tabular}{llccc}
\hline Season & Month & Total sample tested & \multicolumn{2}{c}{ Results } \\
\cline { 3 - 4 } & & & Positive sample & Prevalence (\%) \\
\hline Summer & March & 28 & 6 & 21.43 \\
& April & 54 & 4 & 7.41 \\
& May & 13 & 1 & 7.69 \\
Rainy & & 95 & 11 & 11.58 \\
& June & 22 & 4 & 18.18 \\
& July & 18 & 8 & 44.44 \\
& August & 13 & 6 & 46.15 \\
& September & 34 & 1 & 2.94 \\
\multirow{3}{*}{ Winter } & October & 39 & 1 & 2.56 \\
& & 126 & 20 & 15.87 \\
& November & 14 & 4 & 28.57 \\
Total & December & 72 & 16 & 22.22 \\
& January & 31 & 5 & 16.13 \\
\end{tabular}

Table-6: Prevalence of infectious bronchitis virus according to the region of poultry.

\begin{tabular}{llccc}
\hline S. No. & Region & Total sample tested & \multicolumn{2}{c}{ Results } \\
\cline { 4 - 5 } & & & Positive sample & Prevalence (\%) \\
\hline 1 & Rangpur & 54 & 5 & 9.26 \\
2 & Bogura & 95 & 13 & 13.68 \\
3 & Tangail & 12 & 5 & 41.67 \\
4 & Dhaka & 13 & 2 & 15.38 \\
5 & Gazipur & 88 & 21 & 19.32 \\
6 & Mymensingh & 86 & 1 & 24.42 \\
7 & Jamalpur & 6 & 1 & 16.67 \\
8 & Cumilla & 17 & 65 & 5.88 \\
Total & & 371 & & 17.52 \\
\hline
\end{tabular}

demonstrated by Barua et al. [20]. Another researcher Das et al. [21] finds that a total of 79.38\% sera samples of chickens of selected four districts of Bangladesh were seropositive. Although they do not differentiate the seroprevalence of IBV between vaccinated and non-vaccinated chickens. In Pakistan, overall seroprevalence of IBV was $88 \%$ reported by Ahmed et al. [22]. They represent the antibody status by enzyme-linked immunosorbent assay test procedure that is quite different from molecular prevalence by qPCR tests.

Of three types of chicken, commercial layer chickens were the highest $(42.22 \%)$ prevalence of IBV and lowest prevalence was in broiler chickens. For other two types, it was $17.24 \%$ in Sonali and $14.93 \%$ in broiler breeder chicken. Except broiler, the other three types of chickens reared for more than 60 weeks of age that increased the chances of harbor of IBV infection. Jackwood [23] and Seger et al. [24] reported that the prevalence of IBV in layer is $74 \%$ in Iraq by RT-PCR, whereas $60 \%$ infection carried by 793/B strain of IBV.

The prevalence of IBV had shown a relation in age of chicken. The highest prevalence of IBV was found in the age between 41 and 60 weeks of age of commercial layer and Sonali chicken. On the other hand, it was highest at 21-40 weeks of age in broiler breeder and at 0-16 days of age in broiler.
Javed et al. [14] demonstrated that the IBV is more prevalent in the layer chicken at age $>40$ weeks of age and in broiler chicken at age $>7$ days in Pakistan. However, mortality increased in young chicken than older due to respiratory distress and kidney manifestation [7] and it may reach up to $20-30 \%[25,26]$.

In the present study, the prevalence of IBV becomes highest during winter season (NovemberFebruary) and it was $22.67 \%$. Researchers shown that the incidence of IBV increased during winter season due to cold weather is more favorable to IBV for survival and spread through droplets and dust $[14,23,27]$.

The samples for this study were collected from eight districts of Bangladesh, in which Tangail district revealed the highest prevalence of IBV and it was $33.30 \%$ and the second highest prevalence found in Mymensingh district as $24.42 \%$. It has been mentioned by Sylvester et al. [28], that the transmission and severity of IBV are correlated with flock density. The Tangail and Mymensingh might be the high density of poultry flocks that increased the rates of the prevalence of IBV [29].

Genetically, the S1 gene sequenced data identified that the two serotypes of IBV were circulating during the period of 2014-2016 that is QX-like IBV and 4/91 strains. The comparative analysis S1 gene hypervariable region of IBV in nucleotide sequence is 
a strong tool for the identification of circulating field variants of IBV $[16,30,31]$.

\section{Conclusion}

The study focused on the overview of the prevalence and molecular characterization of IBV circulating in Bangladesh. The overall $17.52 \%$ prevalence with highest in commercial layer chickens comparatively Sonali, broiler, and broiler breeder chickens. The age of chicken over 41 weeks shows more prevalent. The prevalence of IBV ubiquitous round the year but increase prevalence during winter season. According to location, it was highly prevalent in Tangail district. Finally, the sequencing and phylogeny analysis of S1 gene of IBV demonstrated the QX-like IBV and 4/91 strain of IBV were circulating in the environment.

\section{Authors' Contributions}

ZAB, MZA, MG, and ZUMK: Conceived and designed the study. ZAB, MZA, and MMM: Collected samples and performed the experiments and laboratory analyses. MZA: Performed the data analyses. ZAB and MZA: Drafted the manuscript. MMM, MG, and ZUMK: Revised the manuscript critically. All authors read and approved the final manuscript.

\section{Acknowledgments}

This work was financially supported by the Department of Botany, Jahangirnagar University, Dhaka, Bangladesh (Grant number 3894/150) and Animal Health Research Division, Bangladesh Livestock Research Institute, Dhaka, Bangladesh.

\section{Competing Interests} interests.

The authors declare that they have no competing

\section{Publisher's Note}

Veterinary World remains neutral with regard to jurisdictional claims in published institutional affiliation.

\section{References}

1. Kim, Y., Biswas, P.K., Giasuddin, M., Hasan, M., Mahmud, R., Chang, Y.M. and Moyen, N. (2018) Prevalence of avian influenza A (H5) and A (H9) viruses in live bird markets, Bangladesh. Emerg. Infect. Dis., 24(12): 2309.

2. Department of Livestock Services. (2017) Livestock Economy at a Glance 2017-2018. Livestock-Economy, Bangladesh.

3. Ali, M.Z., Rahman, M.M. and Sultana, S. (2015) Seroprevalence of Mycoplasma gallisepticum antibody by ELISA and serum plate agglutination test of laying chicken. Vet. World, 8(1): 9-14.

4. Dhama, K., Singh, S.D., Barathidasan, R., Desingu, P.A., Chakraborty, S., Tiwari, R. and Kumar, M.A. (2014) Emergence of avian infectious bronchitis virus and its variants need better diagnosis, prevention and control strategies: A global perspective. Pak. J. Biol. Sci., 17(6): 751-767.

5. Uddin, M.I., Islam, M.S., Rakib, T.M., Das, S., Kamaruddin, K.M. and Biswas, P.K. (2016) Molecular detection of infectious bronchitis virus isolated from commercial breeder farms in Chittagong District, Bangladesh. Adv. Anim. Vet. Sci., 4(7): 370-375.

6. Bwala, D.G., Solomon, P., Duncan, N., Wandrag, D.B. and Abolnik, C. (2018) Assessment of Mycoplasma gallisepticum vaccine efficacy in a co-infection challenge model with QX-like infectious bronchitis virus. Avian Pathol., 47(3): 261-270.

7. Cavanagh, D. and Gelb, J. (2008) Infectious bronchitis. In: Saif, Y.M., Fadly, A.M., Glisson, J.R., McDougald, L.R., Nolan, N.K. and Swayne, D.E., editors. Diseases of Poultry. $12^{\text {th }}$ ed. Iowa State Press, Ames, Iowa, p117-135.

8. Bickerton, E., Maier, H.J., Stevenson-Leggett, P., Armesto, M. and Britton, P. (2018) The S2 subunit of infectious bronchitis virus Beaudette is a determinant of cellular tropism. J. Virol., 92(19): e01044-18.

9. Worthington, K.J., Currie, R.J.W. and Jones, R.C. (2008) A reverse transcriptase-polymerase chain reaction survey of infectious bronchitis virus genotypes in Western Europe from 2002 to 2006. Avian Pathol., 37(3): 247-257.

10. Woo, P.C., Lau, S.K., Huang, Y. and Yuen, K.Y. (2009) Coronavirus diversity, phylogeny and interspecies jumping. Exp. Biol. Med., 234(10): 1117-1127.

11. Johnson, M.A., Pooley, C., Ignjatovic, J. and Tyack, S.G. (2003). A recombinant fowl adenovirus expressing the S1 gene of infectious bronchitis virus protects against challenge with infectious bronchitis virus. Vaccine, 21(21-22): 2730-2736.

12. Zeng, F., Hon, C.C., Yip, C.W., Law, K.M., Yeung, Y.S., Chan, K.H. and Leung, F.C.C. (2006) Quantitative comparison of the efficiency of antibodies against S1 and S2 subunit of SARS coronavirus spike protein in virus neutralization and blocking of receptor binding: Implications for the functional roles of S2 subunit. FEBS Lett., 580(24): 5612-5620.

13. Britton, P. and Cavanagh, D. (2007) Avian coronavirus diseases and infectious bronchitis vaccine development. In: Thiel, V, editor. Coronaviruses: Molecular and Cellular Biology. Caister Academic Press, Norfolk, UK, p161-181.

14. Javed, T. Siddique, M. and Hameed, A. (1991) Persistence and morpho-pathological studies on infectious bronchitis in chickens in Pakistan. Assiut Vet. Med. J., 25(49): 216-228.

15. OIE. (2004) Manual of Diagnostic Tests and Vaccines for Terrestrial Animals. $5^{\text {th }}$ ed., Vol. 2. Office International des Epizooties $17^{\text {th }}$ Arrondissement, Paris p876-888.

16. Kwon, H.M., Jackwood, M.W. and Gelb, J. Jr. (1993) Differentiation of infectious bronchitis virus serotypes using polymerase chain reaction and restriction fragment length polymorphism analysis. Avian Dis., 37(1): 194-202.

17. Song, C.S., Lee, Y.J., Lee, C.W., Sung, H.W., Kim, J.H., Mo, I.P., Izumiya, Y., Jang, H.K. and Mikami, T. (1998) Induction of protective immunity in chickens vaccinated with infectious bronchitis virus S1 glycoprotein expressed by a recombinant baculovirus. J. Gen. Virol., 79(4): 719-723.

18. Callison, S.A., Hilt, D.A., Boynton, T.O., Sample, B.F., Robison, R., Swayne, D.E. and Jackwood, M.W. (2006) Development and evaluation of a real-time TaqMan RT-PCR assay for the detection of infectious bronchitis virus from infected chickens. J. Virol. Methods, 138(1): 60-65.

19. Core Team (2012) R: A language and environment for statistical computing. R Foundation for Statistical Computing, Vienna, Austria. ISBN 3-900051-07-0.

20. Barua, H., Biswas, P.K., Anwar, M.N., Dey, B.C. and Debnath, M.C. (2006) Serosurvey and isolation of infectious bronchitis virus in chickens reared in commercial and semi-scavenging systems. Bangladesh J. Microbiol., 23(2): 114-117.

21. Das, S.K., Khan, M.S.R. and Das, M. (2009) Seroprevalence of infectious bronchitis in chicken in Bangladesh. Bangladesh J. Vet. Med., 7(1): 249-252.

22. Ahmed, Z., Naeem, K. and Hameed, A. (2007) Detection and seroprevalence of infectious bronchitis virus strains 
in commercial poultry in Pakistan. Poult. Sci., 86(7): 1329-1335.

23. Jackwood, M.W. (2012) Review of infectious bronchitis virus around the world. Avian Dis., 56(4), 634-641.

24. Seger, W., Langeroudi, A.G., Karimi, V., Madadgar, O., Marandi, M.V. and Hashemzadeh, M. (2016) Prevalence of avian infectious bronchitis virus in broiler chicken farms in South of Iraq, 2014-2015. Vet. Res. Forum, 7(4): 317-321.

25. Ignjatovic, J., Ashton, D.F., Reece, R., Scott, P. and Hooper, P. (2002) Pathogenicity of Australian strains of avian infectious bronchitis virus. J. Comp. Pathol., 126(2-3): 115-123.

26. Seifi, S., Asasi, K. and Mohammadi, A. (2010) Natural co-infection caused by avian influenza H9 subtype and infectious bronchitis viruses in broiler chicken farms. Vet. Arhiv, 80(2): 269-281.

27. Hofstad, M.S. (1984) In: Hofstad, M.S., Barnes, H.J.,
Calnek, B.W., Reid, W.M. and Yoder, H.W. Jr., editors. Diseases of Poultry. $8^{\text {th }}$ ed. Iowa State University Press, Ames, IA, p429.

28. Sylvesterm, S.A., Dhama, K., Kataria, J.M., Rahul, S. and Mahendran, M. (2005) Avian infectious bronchitis: A review. Indian J. Comp. Microbiol. Immunol. Infect. Dis., 26(1): 1-14.

29. Ali, M.Z. (2018) The seroprevalence study of Reticuloendotheliosis virus infection in chicken in Bangladesh. Egypt. J. Vet. Sci., 49(2): 179-186.

30. Wang, C.H. and Huang, Y.C. (2000) Relationship between serotypes and genotypes based on the hypervariable region of the S1 gene of infectious bronchitis virus. Arch. Virol., 145(2): 291-300.

31. Ali, M.Z. and Hasan, B. (2018) Follow up of maternally derived antibodies titer against economically important viral diseases of chicken. Poult. Sci. J., 6(2): 149-154. 